$$
\begin{aligned}
& \text { 非熱処理型高張力ボルトの頭部成形応力と軸部強度に及ぼす } \\
& \text { バウシンガー効果と時効の影響十 }
\end{aligned}
$$

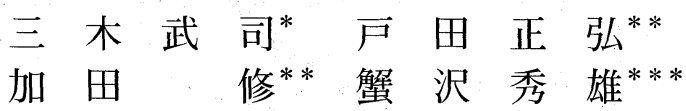

\title{
Influence of Bauschinger Effect and Aging on Heading Stress and Shank-Strength of High-Tensile Bolts without Heat Treatment
}

\author{
by \\ Takeshi MIKI* , Masahiro TodA ${ }^{* *}$, Osamu KAdA ** \\ and Hideo Kanisawa ${ }^{* * *}$
}

\begin{abstract}
At the heading of high-tensile bolt with work-hardend drawing wire, Bauschinger effect appears and raises the tool life. On the other hand, this effect reduces the shank strength of bolt. This paper proposes the steel which has large Bauchinger effect at the heading of drawing wire and the aging process which reduces the Bauschinger effect in the bolt shank. $\mathrm{Mn}$ or Si do not raise the Bauschinger effect. Carbon raises this effect and the high cooling rate after rolling of wire is useful too. Reduction of yield strength and tensile strength of bolt shank after compression are $15 \sim 17 \%$ and $6 \sim 7 \%$, respectively. These reductions in strength are recovered by aging. It is concluded that aging at $573 \mathrm{~K}$ recovers the reduction of yield strength and tensile strength of bolt-shank by the compression under strain no more than 0.03 . During the compression of drawing wire, X-ray diffraction half value breadth which corresponds to the dislocation density indicates constant value. This fact suggests that the number of dislocations which are newly genereted under compression is nearly equal to that which distinguishes by the Bauschinger effect.
\end{abstract}

Key words : Baushinger effect, Iron and steel, High tensile bolt, Plastic working, Flow stress, Work hardening

\section{1 緒—論}

引張強さ $700 \mathrm{MPa}$ 以上の高張力ボルトの製造において 強度を付与する方法は二種類あり, その一つは軟質材を ボルトに成形した後, 焼き入れ焼きもどしによって強度 を付与するものであり, 他の一つは高強度線材をボルト に直接成形するものである。後者に打いては, 冷間鍛造 によって加工すると工具負荷が非常に大きくなるので, 通常は頭部成形を必要としない，ねじ転造のみで成形す るボルト以外に適用することは困難である。そこで，使 用する高強度線材として, 引張強さ $550 \sim 650 \mathrm{MPa}$ 程度 の比較的強度の低い線材を伸線によって加工硬化させ， それを用いて頭部成形すると，極めて容易にボル卜を製 造することができるとされている.1. これは，伸線によっ て導入された線材長手方向のひずみに，頭部成形による 圧縮ひずみが加わって起こるバウシンガー効果を活用し たものである.2

ところが，こうして製造したボルトの引張試験を行う と，伸線後に得られた引張強さが低下することがあると されている.，4) これはボルト軸部がダイス内のクリアラ ンスの存在によって若干の圧縮塑性変形を生じることに より次の引張試験のときに新たなバウシンガー効果が発
現するためであると推定されている。こうした現象は性 能上問題となるのでありその厳密な評価とともに強度低 下を防ぐ方法の検討が必要となる.

一方，バウシンガー効果を低減させるには予ひずみ付 与後に時効させるのが有効であることが知られて打り $\left.{ }^{5)}, 6\right)$ また引張予ひずみ付与後に $523 \mathrm{~K}$ の温度下で圧縮すると 動的ひずみ時効によってバウシンガー効果が低減される ことも知られている. ${ }^{7)}$ ま繰り返し引張一圧縮を負荷さ せた後の時効の影響を見た例 ${ }^{5}$ もあるが，伸線のような 30 ～40\%に及ぶひずみを加えた後の圧縮，引張を重畳す る場合のようなプロセスに抢いて時効がどのように作用 するかについての検討はほとんど成されていない．

さらに, バウシンガー効果の過去の議論は降伏強さに 関するものがほとんどであり，機械部品特性として重要 な引張強さに及ぼす影響について言及された例は非常に 少ない.

ここでは，伸線後のボルト頭部成形時には有効に作用 するバウシンガー効果を活用して工具負荷を低く抑える ための材料条件を求めるとともに, 軸部に生じるバウシ ンガー効果による製品降伏強さ, 引張強さの低下を時効 処理によって補完する方法について検討する. 


\section{2 供試材と実験方法}

\section{$2 \cdot 1$ 供試材}

用いた素材は Table I に示す化学成分を有するもので, 炭素, シリコン，マンガンを種々組み合わせ，一部ニオ ブを添加した。 バウシンガー効果は炭素量が多いほど大 きいことは良く知られている.5.8), 9)ここではさらに圧延 条件の影響も明らかにしてバウシンガー効果を有効に発 揮させる条件を求めるため, 断面 $162 \mathrm{~mm} \times 162 \mathrm{~mm}$ のビ レットを $1523 \mathrm{~K}$ に加熱後直径 $14 \mathrm{~mm}$ に圧延して湯中で 冷却し強度を高めた。

その後 $1173 \mathrm{~K}$ に加熱し, 種々の冷却速度で泠却してフ ェライトーパーライトの形態を変えた。これらの材料の 準備は，バウシンガー効果が材料によりどのように影響 を受けるかを明らかにし，ボルト製造上有効な条件を見 出すためである.

Table I. Chemical composition of steels (mass \%).

\begin{tabular}{|c|c|c|c|c|c|c|c|}
\hline $\mathrm{C}$ & $\mathrm{S} \mathrm{i}$ & $\mathrm{Mn}$ & $\mathrm{P}$ & $\mathrm{S}$ & $\mathrm{C} \mathrm{r}$ & $\mathrm{A} \mathrm{I}$ & $\mathrm{N} \mathrm{b}$ \\
\hline 0.10 & 0.05 & 0.78 & 0.013 & 0.010 & 0.03 & 0.034 & \\
$\tilde{0.44}$ & $0 . \tilde{52}$ & $1 . \tilde{50}$ & $0 . \tilde{0} 14$ & $0 . \tilde{0} 13$ & 0.04 & $0 . \tilde{041}$ & $0 . \tilde{0} 41$ \\
\hline
\end{tabular}

\section{$2 \cdot 2$ 線材の加工}

2・1 節で試作した線材を直径 $11 \mathrm{~mm}$ に冷間伸線（減 面率 $38 \%$ ）した後，素材直径の 1.5 倍の長さに切断した 試験片を用いて, Osakada らの端面拘束圧縮試験 ${ }^{10)}$ に より変形抵抗を求めた。

一方，実生産においてボル卜頭部成形時に発生する軸 部圧縮を精密に再現するために, Fig. 1 に示すように伸 線材を長さ $100 \mathrm{~mm}$ に切断した試験片を素線径より $0.2 \mathrm{~mm}$ 大きな穴径を有するダイスに導入し，上部からパ ンチで押し込む。こうすることにより全長に亘って均一 な圧縮変形を加えるとともに，曲げ変形を最小限に抑え ることができバウシンガー効果の厳密な評価が可能とな る。ここでは押し込み量を種々与えて, 直径を $1 \sim 2 \%$ 増加させた。これはボルト成形の生産ラインにおいて考 えられるボルト軸部からの寸法増加のほぼ上限に対応し

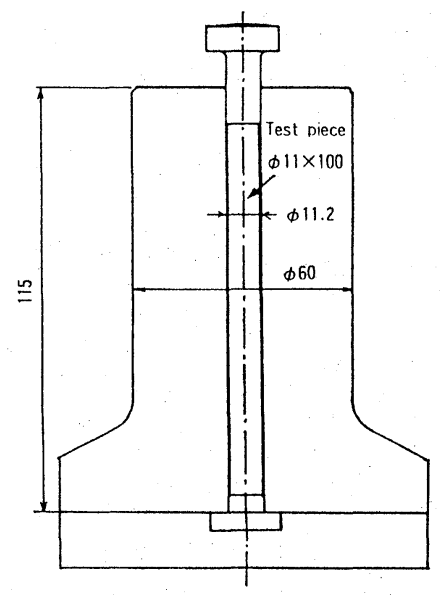

Fig. 1. Subpress for compression of wire.
ている.

伸線後の軸方向圧縮時に現れるバウシンガー効果を第 1 次バウシンガー効果とし, 圧縮後に引張試験を行い, そこで現れる降伏強さや引張強さの低下を第 2 次バウシ ンガー効果とする.

第 1 次バウシンガー効果 ; ボル卜頭部変形 (ひずみ 1.5) を想定して，伸線材を圧縮した時現れるもので, 圧延材 における伸線ひずみと同等の予ひずみを付加したと想定 した場合の変形抵抗に対する圧縮変形抵抗の低下量で評 価する。

第 2 次バウシンガー効果; ボルト軸部変形（ひずみ範 囲：0〜0.04）を想定して伸線材を压縮した後, 引張っ た時現れるもので, 降伏強さ, 引張強さの低下量で評価 する.

軸部圧縮した線材はそのまま引張試験する一方で、軸 部圧縮後に $573 \mathrm{~K} 30$ 分保持し, 時効処理した後の引張試 験も行い, その効果を確認した。

\section{3 実 験 結 果}

\section{$3 \cdot 1$ 伸線一圧縮時に発現する第 1 次バウシンガー効果}

Fig. 2 にひずみ 1.5 における伸線材と圧延材の圧縮変 形抵抗 $\sigma_{F}$ を，それでれの引張強さとの関係で示す。こ こで用いた線材は炭素 $0.2 \%$ (mass \% 以下同じ)，マンガ ン $1.5 \%$ を基本成分としてニオブ $0.04 \%$ を含んだものと， 含まないものを比較した。 この図において, 直径 $14 \mathrm{~mm}$ の圧延材同士の結果を比較すると, C-Mn-Nb 鋼より C$\mathrm{Mn}$ 鋼の方が同一強度に対する変形抵抗は低くなる。こ のことはそれらの直径 $11 \mathrm{~mm}$ の伸線材においても同様で あるが，同一の引張強さに対して整理すると伸線材の変 形抵抗は圧延材の光れらに対してはるかに低くなる。

このことは，伸線によって線材は引張変形に対して強 度は上昇し続けるが, 圧縮変形には筆者らが既に報告し たように，伸線で導入された転位の一部が容易に移動し， また消滅するバウシンガー効果が発現したためと考えら れる.2)この図から明らかなように伸線材は引張強さが高 いにもかかわらず，ボルト成形時の工具負荷は高くなる ことなく，工具に対する負荷が圧延材と同等以下になる. また，この図で見たようにこれまで一般に用いられてき た $^{1)}$ ニオブは, バウシンガー効果に関しては必ずしも有

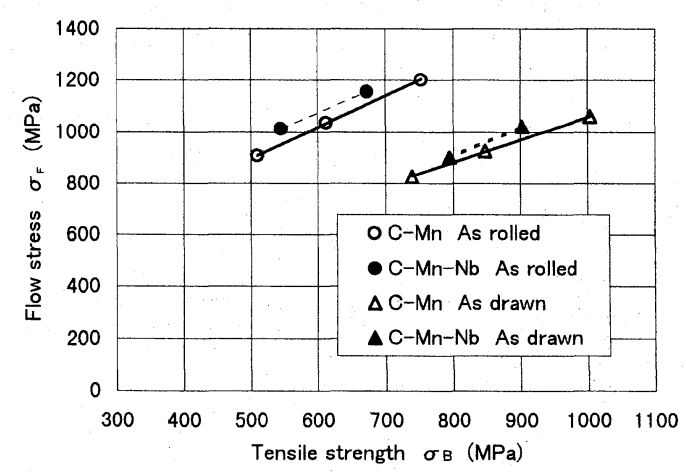

Fig. 2. Relation between flow stress and tensile strength of rolled or drawn wires.

C $0.2 \%, \mathrm{Mn} 1.5 \%, \mathrm{Nb} 0.04 \%$, Compressive strain 1.5 . 
効ではないことが分かる.

次に，この第 1 次バウシンガー効果の，材料による差 を明らかにするため，伸線材を圧縮するときの変形抵抗 の，圧延材における伸線ひずみ相当分の予ひずみを加算 した圧縮変形抵抗からの低下量 “FR”を整理したのが， Fig. 3 である. この図は, 基本成分はマンガン $1.5 \%$, 二 オブ $0.04 \%$ として炭素量を横軸に取り，圧縮ひずみ 1.0 の時の変形抵抗の低下量を示している。結果は, 炭素量 の増加に伴い変形抵抗の低下量は大きくなっており, 最 大 $200 \mathrm{MPa}$ に達する.この炭素量がバウシンガー効果に 及ぼす影響は，熊倉によって報告されている傾向と一致 する. この図で, ニオブの影響はほとんどない.

一方，Fig. 4 はともに $0.2 \%$ 炭素を含有する場合で， マンガン，シリコンを実用の範囲内で変化させたときの バウシンガー効果による圧縮変形抵抗の低下を見たもの であるが，これらの成分の影響はわずかであり，炭素の 影響よりはるかに少なかった。

次に，圧延後の冷却速度の影響を見るために，圧延材 を $1173 \mathrm{~K} 15$ 分加熱して種々の条件で冷却した結果が Fig. 5 である. 困には基本成分をマンガン $1.5 \%$ ，二オブ $0.04 \%$ とし, 炭素量は 0.1 と $0.2 \%$ の場合について冷却速度を変 化させたときの第 1 次バウシンガー量を示している. $0.02 \mathrm{~K} / \mathrm{s}$ は炉中冷却， $3 \mathrm{~K} / \mathrm{s}$ は放冷， $7 \mathrm{~K} / \mathrm{s}$ は湯中冷却の 場合である。

この図より，いずれの炭素量でも冷却速度とともに第

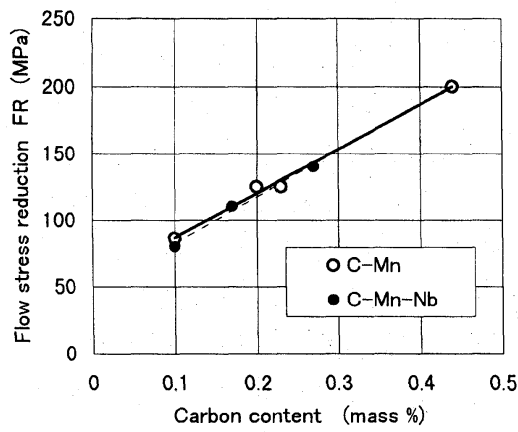

Fig. 3. Relation between carbon content and "FR" at the compressive strain 1.0 .

FR; Flow stress reduction of drawing wire from that of rolled wire at the compressive pre-strain correspond to drawing strain.

Mn 1.5\%,Nb0.04\%

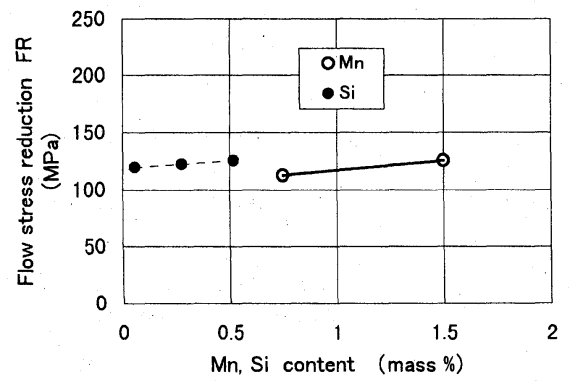

Fig. 4. Relation between Mn or Si content and FR. 0.2\% $\mathrm{C}$ as drwan wire.
1 次バウシンガー効果は大きくなり，ことに $3 \mathrm{~K} / \mathrm{s}$ を超え てから急増する。これはフェライトーパーライト組織に おいてパーライト分率の急増に詨応していると考えられ る. 例えば $0.1 \%$ 炭素鋼では冷却速度 $3 \mathrm{~K} / \mathrm{s}$ から $7 \mathrm{~K} / \mathrm{s}$ の 間に，パーライト分率は $18 \%$ から $24 \%$ に増加している。 このように同一炭素量でもパーライト分率の影響は大き く，第 1 次バウシンガー効果を高めるには，压延後の急 冷が有効であることが明らかとなった。

\section{$3 \cdot 2$ 伸線材を用いたボルトの試作}

$3 \cdot 1$ 節の結果を参照してボルトを試作した。すなわち， 炭素量は高め，圧延後の冷却速度は高めを選択する。

Table IIに用いた素材の化学成分を示す. Steel A は, 従来多用されていた Steel B に比較して炭素量が多く, ニオブは除去している. Steel A は, 圧延後の冷却速度 を $7 \mathrm{~K} / \mathrm{s}$ とし, Steel B は $5.5 \mathrm{~K} / \mathrm{s}$ とした。

これらの直径 $14 \mathrm{~mm}$ の圧延材を直径 $11 \mathrm{~mm}$ に伸線し た後，引張強さは Steel A が $814 \mathrm{MPa}$, Steel B が $799 \mathrm{MPa}$ とほぼ同等であった。この線材を軸方向に据え 込み, 変形抵抗を求めた. Fig. 6 はその結果を示し, 全 体的にSteel Aの変形抵抗は低く, 実際のボルト頭部を ヘッディングするときに相当するひずみ 1.5 の時の変形 抵抗は Steel B の 1010MPa に比べて, Steel A は 900MPa で, 約 $10 \%$ 以上低い。 これは, 工具寿命向上に極めて有

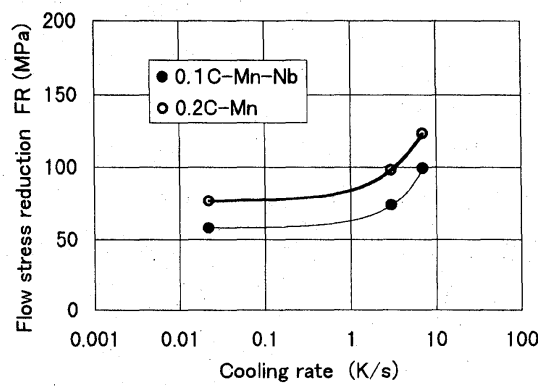

Fig. 5. Influence of cooling rate after rolling on FR. $\mathrm{Mn} 1.5 \%, \mathrm{Nb} 0.04 \%$ as drawn wire.

Table II. Chemical composition of steels (mass \%).

\begin{tabular}{|c|c|c|c|c|c|c|c|}
\hline & $\mathrm{C}$ & $\mathrm{S} \mathrm{i}$ & $\mathrm{Mn}$ & $\mathrm{P}$ & $\mathrm{S}$ & $\mathrm{A} \mathrm{I}$ & $\mathrm{N} \mathrm{b}$ \\
\hline Steel A & 0.24 & 0.23 & 1.48 & 0.023 & 0.010 & 0.042 & - \\
\hline Steel B & 0.13 & 0.26 & 1.35 & 0.014 & 0.017 & 0.026 & 0.038 \\
\hline
\end{tabular}

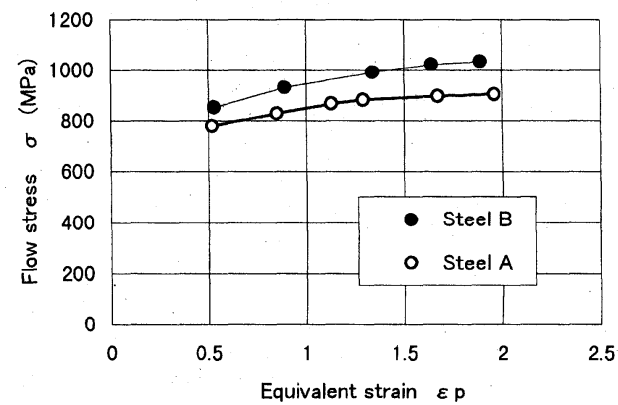

Fig. 6. Flow stress of the drawn wire under compression test. as drawn wire. 
効である.

以上のように，炭素を高めかつ圧延後の急冷によりパ ーライト分率を高めることがボルトヘッディングにおい てバウシンガー効果がより有効に活用できることが明ら かになった。

\section{$3 \cdot 3$ 軸部圧縮, 時効後の引張試験}

$3 \cdot 2$ 節ではボルト頭部成形を考えて, バウシンガー効 果が有効に作用し，より有利な材料選定ができたが，同 時にボルト軸部が圧縮されることにより生じるバウシン ガー効果がどの程度ボルトとしての引張特性を低下させ るかを明らかにしておく必要がある．Fig. 7 は軸圧縮荷 重とその負荷後の直径増加の関係を示し, $100 \mathrm{~mm}$ の試 験片全長に亘って $\pm 0.01 \mathrm{~mm}$ 以内の変動幅で極めて均一 な直径の増加が起こっているとともに曲がりはほとんど 発生していないことが分かる。この試験片をそのまま引 張試験に供した。

Fig. 8 (a), (b) は Steel A と B のボルト成形時に想定さ れる軸部の圧縮後と，それを時効処理した後の引張試験

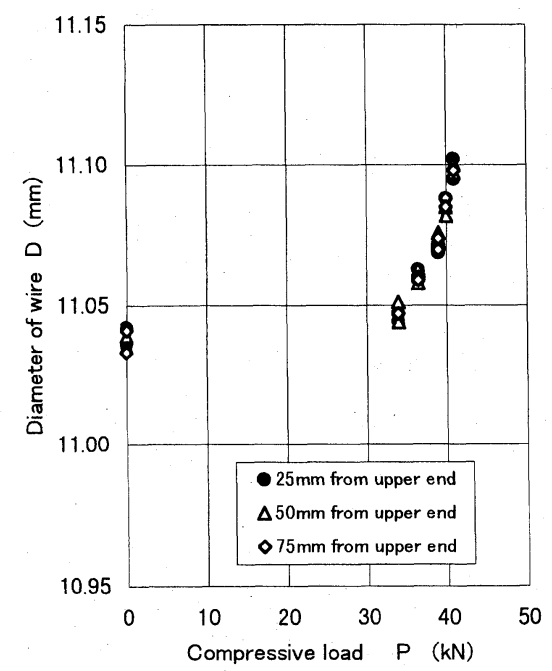

Fig. 7. Change in diameter by compression. Steel $\mathrm{A}$ as drawn wire.

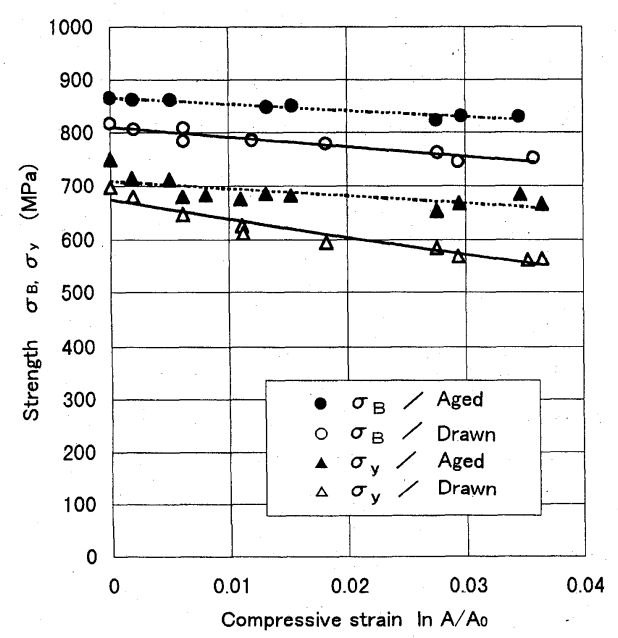

(a) Steel A
結果を示した図である。なお図中の圧縮ひずみとしては 圧縮前後の軸部断面積の変化を対数ひずみ $\ln \mathrm{A} / \mathrm{A}_{0}$ とし て与えた。いずれの鋼種においても実験範囲の圧縮では， 圧縮ひずみの増加とともに引張強さおよび降伏強さがほ ほ值線的に低下し続ける。また，圧縮による応力の低下 率は, 引張強さより降伏強さのほうが大きい, 一方, そ れらを時効処理すると引張特性は一様に向上し, 引張強 さで $40 \sim 75 \mathrm{MPa}$ ，降伏強さで $25 \sim 120 \mathrm{MPa}$ 増加する. ことに圧縮ひずみの大きい場合の向上が大きい.この時 効処理により，圧縮によって低下した降伏強さ，引張強 さはともにほぼ圧縮前のレベルに回復した。

Fig. 9 (a)〜 (d) は, Fig. 5 の結果から Steel A, Bにつ いて圧縮前の降伏強さ, 引張強さと, 時効処理した後の それらの増減率を求めたものである. Steel A, B ともほ ぼ同様の傾向を示す.

直径増加 1.5\%（ひずみ 0.03）の圧縮による降伏強さの 低下量は, Steel A ; 14.8\%, Steel B ；17.3\%. 引張強さ の低下量は, Steel A ; 7.1\%, Steel B ；6.5\% となった.

一方，伸線後の圧縮ひずみ 0.03 以内では時効処理によ り，ほぼ圧縮前素材の降伏強さ，引張強さに回復する。 よって伸線後に最終必要強度を与えておけばボルト成形 時のバウシンガー効果による強度低下分は時効処理で回 復できることが分かる。

第 1 次バウシンガー効果は Steel Aのほうが明確に大 きかったが, この第 2 次バウシンガー効果においては材 料差はほとんど見られなかった。 即ち, 非調質型高張力 ボルトの製造は第 1 次バウシンガー効果の高い条件を選 定し，ボルト成形後に時効処理によって軸部強度低下を を回復させておけば所定の強度を達成することが明らか になった。

\section{4 考察}

本稿において第 1 次バウシンガー効果は, 炭素量が多 く，圧延後の冷却速度の高い場合にことに大きく現れる ことを見た. 一方, 第 2 次バウシンガー効果は第 1 次バ ウシンガー効果に比べて材料による差は小さく, 降伏強

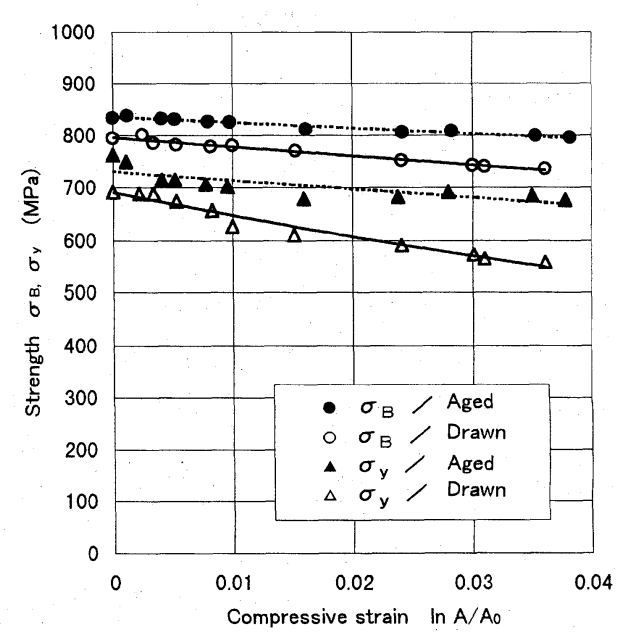

(b)Steel B

Fig. 8. Yield strength and tensile strength of drawn wire after compression and subsequent aging. 


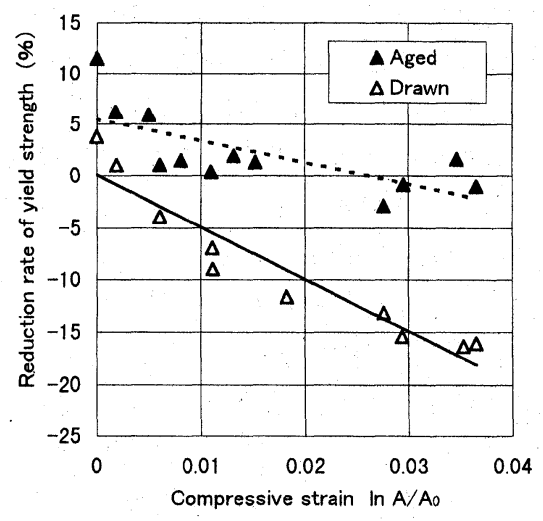

(a)Steel A, Yield strength

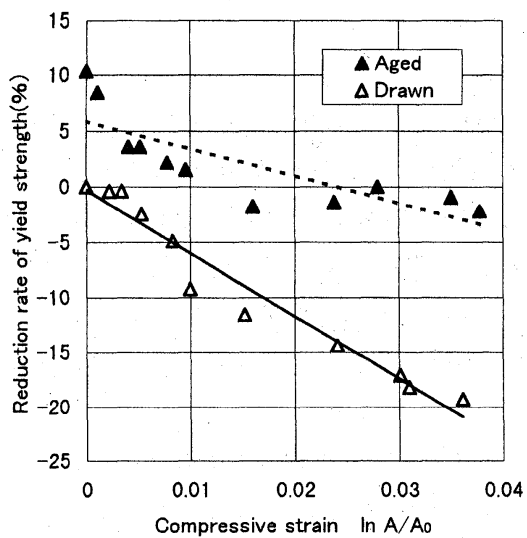

(c)Steel B, Yield strength

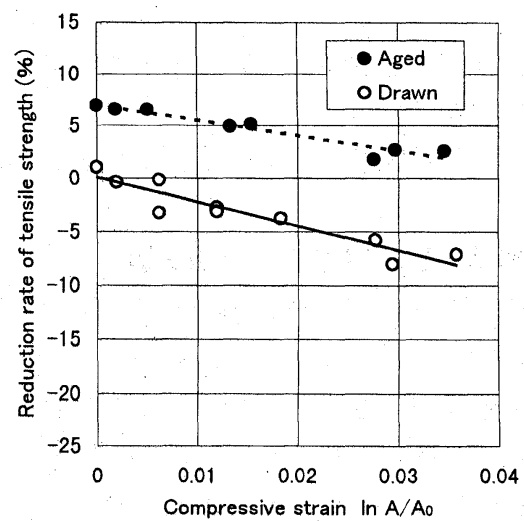

(b)Steel A, Tensile strength

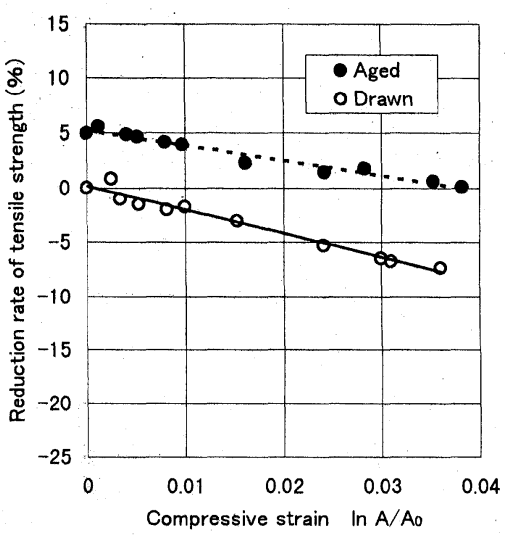

(d) Steel B, Tensile strength

Fig. 9. Reduction rate of yield strength and tensile strength after compression and after aging compared with as drawn wires.

さおよび引張強さに関してもほぼ同等である。

さらに, 圧縮後の時効処理によって降伏強さ, 引張強 さは一様に上昇し，その上昇量は圧縮ひずみとともに大 きくなる．また，引張強さの上昇より降伏強さの上昇の 方が大きい。このことは第 2 次バウシンガー効果が引張 強さよりも降伏強さに大きく発現することに関与してい ると思われる.

第 1 次バウシンガー効果が大きければ第 2 次バウシン ガー効果も大きいことが予想されるが，ここではその相 関性はほとんど見られなかった。 ここで定義した第 1 次 バウシンガー効果は，伸線によって与える予ひずみは 0.3 〜0.5 ほどあり, しかもその後の庄縮ひずみは $1.0 \sim 1.5$ に上る. 一方, 第 2 次バウシンガー効果は, 第 1 次予ひ ずみ $0.3 \sim 0.5$ に $0.03(1.5 \%)$ 程度の第 2 次予ひずみを与 えた後の引張降伏時すなわち $0.2 \%$ 永久ひずみに対応する 応力のとき，および引張強さの発現時即ちひずみがおよ そ $0.1 \sim 0.2$ 前後の時である.

これまでのバウシンガー効果の研究の多くは降伏点を 超えて数％の範囲のひずみ域を対象としているため，そ れらの知見とここの結果を対比することは困難である.

Ring らは本稿と同じような観点で伸線（直径 $10.5 \mathrm{~mm}$

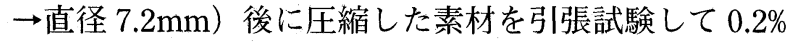
降伏強さの低下が $1.7 \%$ 圧縮材で条件によっては最大 40 〜 50\%に達するとしている.）帛の時用いられた鋼種は炭 素量が $0.08 \sim 0.15 \%$ と本稿の種々の鋼種と比較して低い 部類に属するものである. ところが第 2 次バウシンガー 効果に相当するものは本稿の鋼種よりかなり大きい. 圧 延後の冷却条件の影響が大きいが前述した本稿の冷却設 備は線材製造の設備としては非常に冷却速度の高い条件

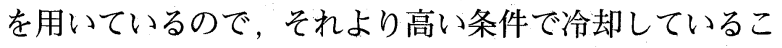
とは考えにくい．伸線後の圧縮においてここではほとん ど曲げ変形を受けないよう細心の注意を払って行った。 一般にバウシンガー効果の実験では短尺の試験片で実施 されていることが多いため曲げ変形が発生しやすく，そ の場合圧縮により局部変形が起こって, 降伏が低荷重で 起こる可能性がある。ここではそうした㲘念は全くない のでバウシンガー効果が小さめに出たことが考えられる.

一方，降伏強さと引張強さは時効处理によって大きく 上昇する．時効处理による強度の上昇は，鉄中に固溶し ている炭素や窒素が $573 \mathrm{~K}$ の加熱によって転位と結合し， 動きを拘束するために只の後の変形抵抗を上げるもので ある，従って，圧縮ひずみの増加によって転位の消滅， 


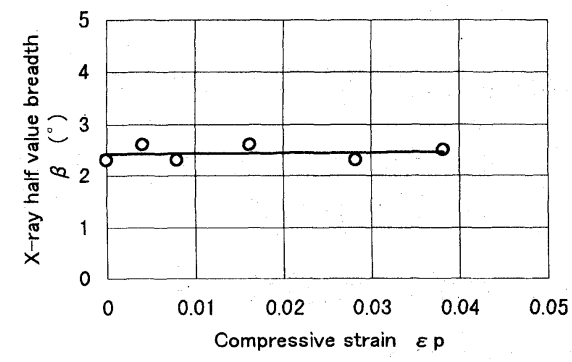

Fig. 10. Influence of compression strain on X-ray halfvalue bredth. Steel $A$ as drawn wire.

発生が起こるが, その後の引張における降伏強さや引張 強さの低下に関わるのは圧縮時に動いて逆応力を発生さ せる状態になっている転位と考えられる。

そこで, 伸線後の圧縮によって転位密度がどのような 変化をするか X 線回折法による半価幅 $\beta$ を近似的指標と して用いることによって検討した. Steel A の伸線材を 用い, $\mathrm{X}$ 線は平行ビーム応力測定設備により $\mathrm{Cr}-\mathrm{K} \alpha$ 線を 当てて $\alpha$ 鉄の (211) 面の回折を得た。この半価幅を圧縮 ひずみに対応して整理したのが Fig. $10 て ゙ ，$ 伸線後のひ ずみ 0.04 の圧縮過程ではほとんど転位密度は変化しない ことが分かる。これは伸線で導入された転位の庄縮によ る消滅と，新たな転位の発生がほぼ相殺したものと考え られる。

このように転位密度が変化しない領域, 即ち圧縮ひず み 1 ～2\%の負荷後において時効処理を施すと，転位に 炭素, 絰素が結合して変形抵抗を上げ, ひずみ 0.03 以下 では伸線まま材の降伏強さ $\sigma_{y}$, 引張強さ $\sigma_{B}$ まで回復す ることが明らかになった。こうした結果は, バウシンガ 一効果の原因となる逆方向応力によって容易に動く転位 が, 時効によって炭素, 絰素の固着が起こりバウシンガ 一効果の発現を押さえ达むためと考えられる.

\section{$\mathbf{5}$ 結 論}

伸線後のボルト頭部据込み時に発生するバウシンガー 効果，扔よびその時同時に生じるボルト軸部の圧縮によ る軸部強度低下とそれを補完する時効の影響について実 験し, 以下の結論を得た。

（1）伸線後の頭部据込み成形時に発現する第一次バウ
シンガー効果を高めるには，炭素量増加とともに，圧延 後の急冷によるパーライト分率の増加が有効であり, マ ンガン, シリコン, ニオブ等の影響は小さい.

(2) 伸線材の頭部据込み成形時にボルト軸部もダイス クリアランスの範囲内に打いて軸方向の圧縮塑性変形を 受けるため, ボルト成形後の軸引張時に降伏強さ $20 \%$ 以 内, 引張強さ $10 \%$ 以内の低下が起こる。この軸部の第二 次バウシンガー効果の発現には鋼種の影響は大きくない.

（3）伸線後の軸部圧縮工程に打いて，X線半価幅はほ とんど変化せず，この過程に打いて転位の発生消滅のバ ランスが取れていることが明らかとなった。この状態で 時効させると圧縮時に逆応力を発生していた転位を固定 し，引張時の動きを拘束して強度が上昇する。

（4）軸部の圧縮による強度低下に対して時効の影響は

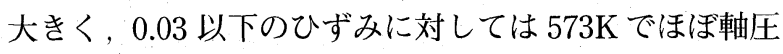
縮前の降伏強さ，引張強さに回復する。この回復率は圧 縮予ひずみが大きく引張時に発現するバウシンガー効果 の大きい場合ほど大きい。

以上の結果，ボルト頭部据込み成形時にはバウシンガ 一効果を極力大きく利用できる材料を選定するとともに， 同時に起こるボルトの軸部強度低下を抑える時効处理条 件を見出すことが出来た。

\section{参 考 文 献}

1）芹川修道，熱处理，24，25（1984）.

2）三木武司，戸田正弘，材料，38，398 (1989).

3) E. Walper, H. Koehler, K. Esselborn and G. Roth, Steel Research, 64, 437 (1993).

4) M. Ring and W. Dahl, ibid., 64, 522 (1993).

5) 熊倉重典, 日本機械学会誌, 70, 1287 (1967).

6) D. N. Williams, Metall. Trans. A, 11A, 1629 (1980).

7) C.-C. Li, J. D. Flasck, J. A. Yaker and W. C. Leslie, ibid., 9A, 85 (1978).

8) D. V. Wilson, Acta Met., 13, 807 (1965).

9）友田 陽，田村今男，鉄と鋼，67，439（1981）.

10) K. Osakada, T. Kawasaki and K. Mori, Ann. C. I. R. P., 30, 135 (1981). 